\title{
A113 傾斜設置されたフィンチューブ熱交換器の管外流動特性
}

\author{
都立大 山口 $\bar{\tau}^{\circ}$, 坂本 守義, 日 立 喜久川修一; (学) 稲葉邦彦
}

Analysis of Flow Characteristic of Inclined Fin-tube Heat Exchanger

\author{
Hajime YAMAGUCHI*, Moriyoshi SAKAMOTO*, Syuichi KIKUKAWA** . \\ and Kunihiko INABA*.
}

\begin{abstract}
Flow characteristics across a fin-tube heat exchanger, which is installed at an angle to air stream in the flow passage of the air-conditioning equipment, are investigated. Already, velocity measurements and flow visualizations are performed in both the inlet and exit chamber of the heat exchanger. As for the flow characteristics in the equipment are in general agreement with results of flow visualization tests implemented in the test section which was made with particularly manufactured Plexiglas. Also, numerical calculation results on the flow patterns by the finite volume method agree well with flow visualization results. Analytical and experimental attempts help us to understand effects of the flow incidence angle and Reynolds number on the performance of the heat exchanger. Lastly, it compared the flow characteristics of in-line arrangement tubes model which manufactured newly and staggered arrangement tubes model by the visualization methods.
\end{abstract}

1. 緒言

半導体製造施設などでは市場のニーズの多様化に伴って頻繁に工場レイアウトの変更を行なわなければならい.これ に対して中央管理による空調設備では個々の条件に則した設定がしにくいことから, 移動が容易でかつ設備場所単位で 調節が可能な分散型空調システムが要求されるようになってきた。この傾向は益々強くなっており，この結果空間的な 制約が緩和され，レイアウト設計の自由度が緩和される傾向が顕著である.かかかる状況下で，コンパクトでかつ高性能 な設備への要求が高まっている.この対処の一手法として, 空気流入方向を熱交換器正面からの流入ではなく，斜めか

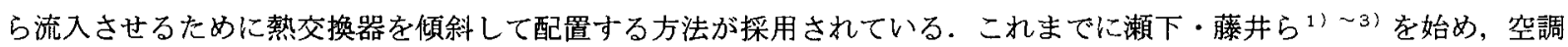
装置用熱交換器の性能評価は盛んに行われている。しかしこのような設置条件に対する性能調查は未だ行われておら ず，状海の把握もないまま過大スペックに依存して性能を確保している状況にある.

そこで, 本研究では, 実機の熱交換器による流入・流出断面の速度分布を把握した上で4)，実機フィン 1 ピッチ空 間の円柱群千鳥配列モデルを作製し, 傾斜流入条件を再現し, 熱交換器内部の流動状況を定性的・定量的に調査するこ とを試みた。その結果，これまでの実機に基づく流入・流出の流動状況の推移を明確に理解することができた。特に， 流入傾斜角度, 円柱群の有無, $R e$ 等の諸条件の影響を詳細に実験調査し, 系統的な状況の把握を可能にした.この結果, 傾斜して設置された千鳥配列の円柱群を流れる流動 様相が極めて複雑かつ多様な経過をたどることが確 認された。しかし，流動場としては比較的繰り返し の多い円柱群の配列下の流れであることから, 流動 特性の数值シミュレーションを有限体積法により試 みた ${ }^{51}$. 数值シミュレーションの結果は流動状況の 実験結果とも相関は良好であることを確認した。さ らに円柱群碁盤配列モデルを新たに製作し，千鳥配 列に打ける流動との相違について可視化実験結果を 比較し考察行った.

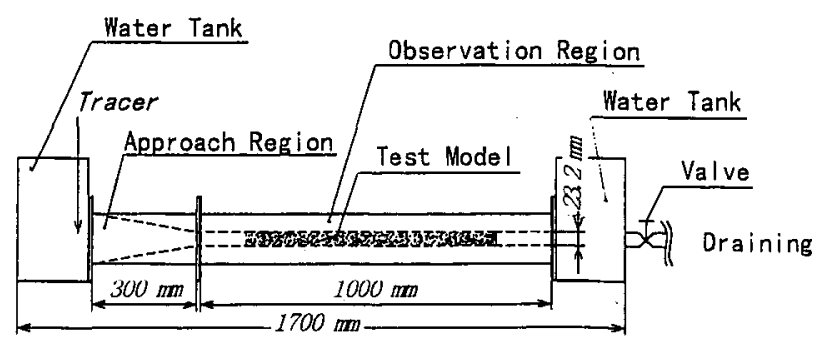

Fig. 1 Experimental equipment

* Faculty Engineering, Tokyo Metropolitan University, 1-1, Minami-Ohsawa, Hachioji-shi, Tokyo 192-03.

** Hitachi Ltd., 4-1-1, Suwa-cho, Hi tachi-shi, Ibaraki-ken 316. 


\section{2. 実験装置・条件}

実験用水流装置の概要を図 1 に示す.この水流装置は貯 水用器, 助走域, 観察部, 排水部により構成される. 可視 化実験では，トレーサに万年筆用の青インクを用い, 貯水 容器から注射器により実験流路へトレーサを注入した。 デル内部の流動は, 観察部上方に配置したビデオカメラに より撮影した. モデル前面の平均流速 $\bar{u}$ の算出には, 水槽 バルブ部より排出される流量の測定值をモデル前面の流路 断面積で除することで求めた。 なお、円柱群内部の流速を

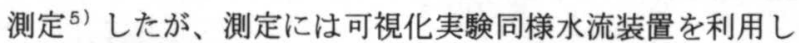
水流中で行った. トレーサとして直径約 $1 \mathrm{~mm}$ のナイロン粒 子を実験流路に注入し, ストロボ光源を照射させ, 観察部 上方からカメラで撮影した. シャッタースピードは $1 / 30$ 秒, ストロボ周波数は $120 \mathrm{~Hz}$ である.これらの写真からトレー サ粒子の流跡の長さを求め, 円柱群内部の流速を算出した.

図 2 に水流装置観察部に配置した実験流路を, 表 1 に可 視化実験条件を示す. 実験流路は, 入口流路, 観察用模型, 出口流路からなり, 出入口流路によりモデルの傾斜角度 $\theta$ を変化させた. 観察部には, 実機の熱交換器 1 フィンピッチ空間をアクリルで作製し，円柱 群千鳥・碁盤配列の 2 モデルと, 円柱群を取 り除いたモデルの 3 種類を使用した. 円柱群 モデルは伝熱管を円柱群で置き換えた熱交換 器モデルである. モデルの仕様は円柱段数: 16 , 列数: 8 , 円柱径: $16 \mathrm{~mm}$, 段ピッチ: $38 \mathrm{~mm}$, 列ピ ッチ $33 \mathrm{~mm}$, フィンピッチ $3.2 \mathrm{~mm}$ とした.

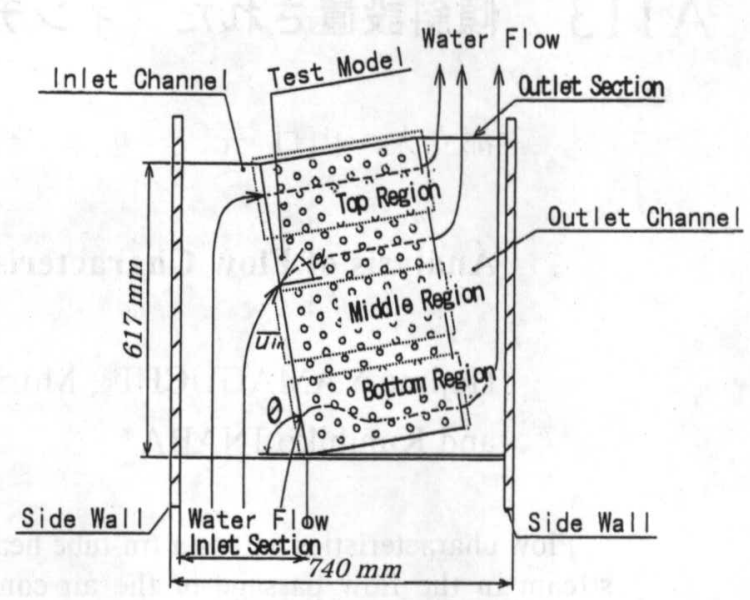

Fig.2 Experimental flow pass

\section{3. 熱交換器傾斜角度が流れに及ぼす影響}

図 3 に熱交換器傾斜角度が $\theta=80^{\circ}, 45^{\circ}$ に相当する円柱千鳥配列モデル下部の可視化実験と, 対応する範囲の計算 結果 ${ }^{5)}$ の流動特性の比較を示した. 実機熱交換器と同条件の $\theta=80^{\circ}$ では, 円柱モデル流入口の流速がモデル下部では

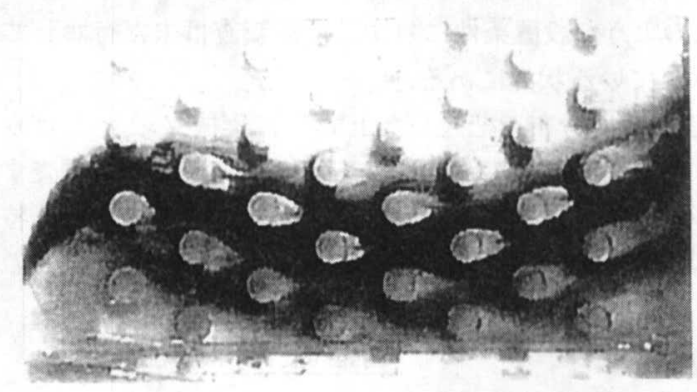

(a) $\theta=80^{\circ}$ (Visualized photograph)

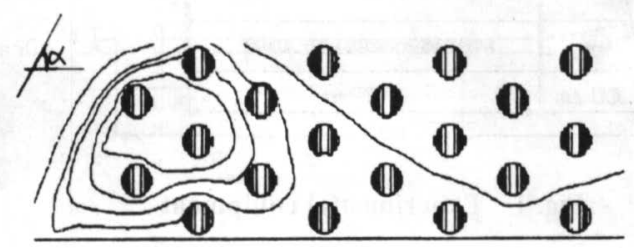

(b) $\theta=80^{\circ}$ (Calculated result) ${ }^{5)}$

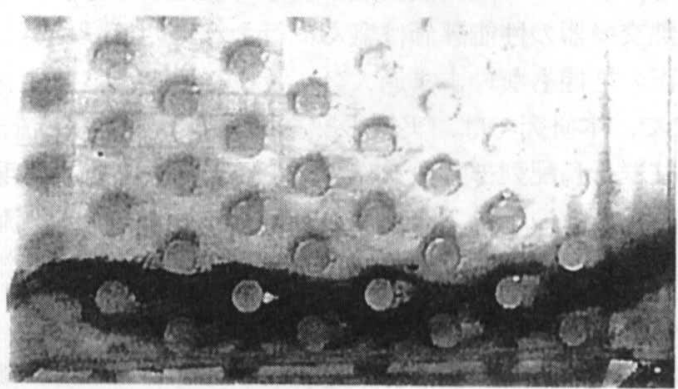

(c) $\theta=45^{\circ}$ (Visualized photograph)

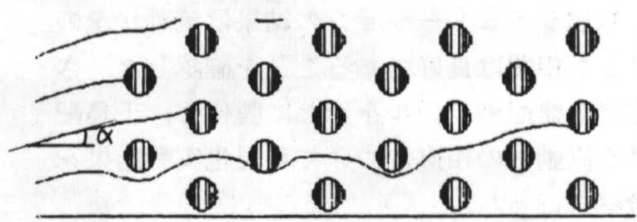

(d) $\theta=45^{\circ}$ (Calculated result) ${ }^{5)}$

Fig.3 The comparison of the characteristic of the flows by the difference of $\theta$ (Bottom region, $R e=1300$ ) 
大きく，上部ほど減少することが確認される. 流入方向はモデル下部では入口面に直交する面からおよそ $80^{\circ}$ (図 2 中 の $\alpha$ ), 右上方向に流入するのに対し, 上部ほど角度 $\alpha$ は小さくなり, モデル上部でほぼ入口面の直交方向（ $\alpha<30^{\circ} ）$ に流入する. 円柱群内部の流動を観察すると, モデル上部では流入後に流速は加速し, モデル上壁と平行な方向に流れ ることが確認される，一方，モデル中央部では，右上方向より流入後，流れは，次第にモデル上下壁と平行となり，3 列目の円柱群以降ほぼ上下壁と平行に流れる. その間モデル上部と比較し内部で流速はほとんど加速されない. モデル 下部では, 流入後の流速は急激に減速し, 流動方向はモデル下壁と平行よりやや右下となる. また, 下壁近傍は速度が 極めて小さく，モデル左下は止水域となる.

モデル傾斜角 $\theta=45^{\circ}$ では, モデル上部の流動現象は $\theta=80^{\circ}$ の場合と差違はほとんどないがモデル下部ほど違いが顕 著となる. $\theta=45^{\circ}$ では下部の流入角度 $\alpha$ は約 $10^{\circ}$ で, 円柱群内部ではあまり減速せず, モデル左下に止水域はない.

以上のことから, 熱交換器の傾斜角度 $\theta$ により内部の流動現象は大きく影響されることが確認できる. ただし, 円柱 群内部での流速の変化, 流入角度の差違は流路入口・出口断面積とモデル断面積の流路断面積に顕著に影響されるもの と推測される.

\section{4.内部の円柱群が流れに及ぼす影響}

図 4 では可視化写真により, 熱交換器モデル内部の流動特性を円柱群の有無によって比較した. 円柱群配列があるモ デル流入口ではモデル下部で流入角度 $\alpha$ が最も大きく, 上部ほど小さくなる. モデル内部の流動を観察すると, モデル 上部では加速流, 中央部では等速流, モデル下部では減速流となり, 左下に止水域が存在する.これらの流動特性は, 円柱群なしのモデルでも確認される. 円柱群なしモデルと, 円柱群配列モデルでの流動を比較すると, 流路内に円柱群 を配置することで, 熱交換器モデルの左下部の止水域が縮小し, モデルに流入・流出する速度分布は少し均一化される ことが確認でき, むしろ流路断面積の変化が傾斜設置された熱交換器内部の流動特性に大きく影響すると判断できる.

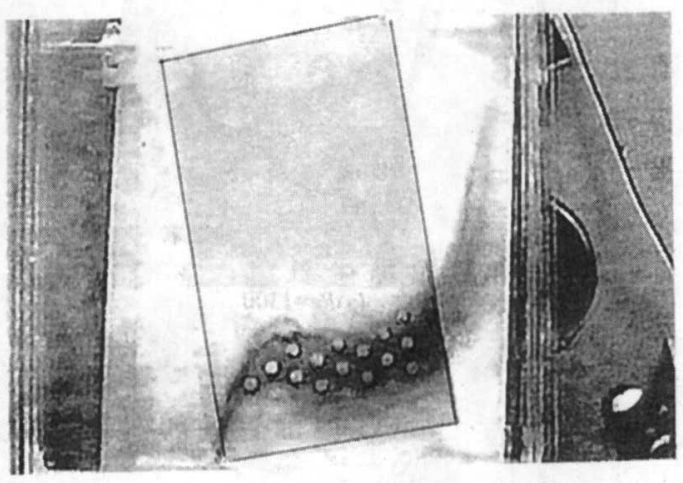

(a) existence of columns

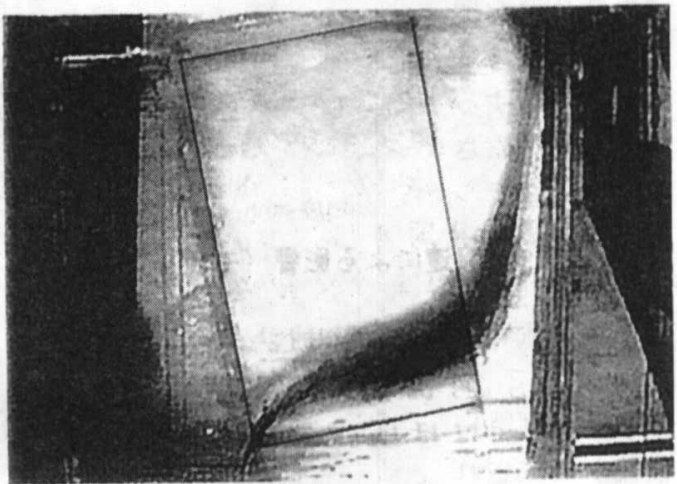

(b) non-existence of columns

Fig.4 Comparison of flow characteristics by the existence or non-existence of columns

(Bottom region, $R e=1300$ )

\section{5. 流入流速あるいは Reが流れに及ぼす影響}

図 5 に流速 $(R e)$ の相違による流動特性の比較を示す. 実験ではモデル前面の平均流速を, $18 \mathrm{~m} / \mathrm{s}, 0.1 \mathrm{~m} / \mathrm{s}, 0.06 \mathrm{~m} / \mathrm{s}$

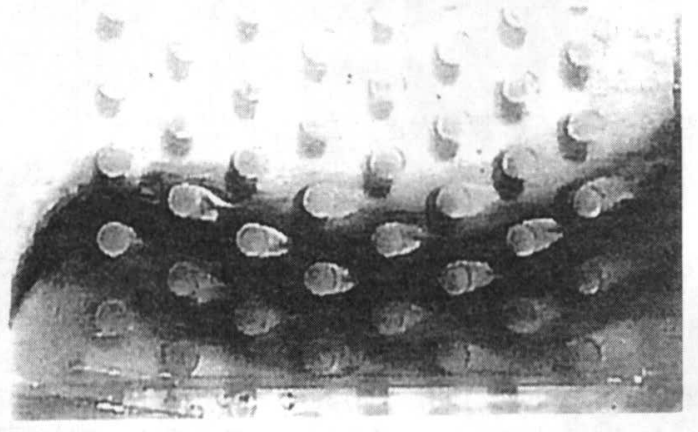

(a) $R e=1300$

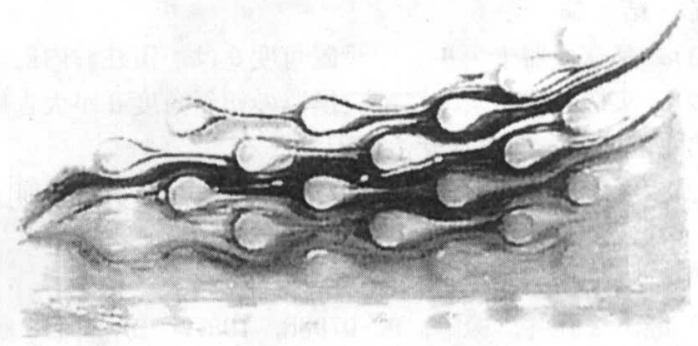

(b) $R e=300$

Fig.5 Comparison of flow characteristics by differences of $R e$ (Bottom region, $R e=1300$ ) 


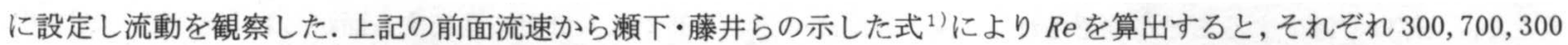
程度となる. $R e=1300$ は本実験で対象とする空調装置と同じ $R e$ 領域である. $R e=700$ はコンパクト熱交換器では比較 的高流速領域であり, $R e=300$ は家庭用ルームエアコン等コンパクト熱交換器の最も一般的な使用領域である. 各実験 結果を比較すると, 局所的に円柱背後の後流部に生成される渦運動に変化があるものの, モデル上部・中央部では流速 の変化によりインクの流動方向はほとんど変らない，モデル下部では内部の流動に多少影響が見られ，流速の減少に伴 い, $\alpha$ が小さくなり左下部の止水域が減少する. しかし, 低い $R e$ 領域においても流動の樣相は同一傾向を示していた. この結果, 前述のモデル設置角度 $\theta$ の方が $R e$ よりもモデル内部の流動特性に及ぼす影響が大きいと考えられる. 従っ て, 気流中に傾斜設置された熱交換器内部の流動特性は, 熱交換器の傾斜角度 $\theta$ に大きく影響すると判断される.

\section{6. 円柱群配列の相違が流れに及ぼす影響}

図 6 に円柱群が千鳥配列の場合と碁盤配列の場合の流動の比較を示寸.千鳥配列については $\theta=80^{\circ}, R e=1300$ の条 件に関し流動状況を前節 3 に記述した. 同条件の碁盤配列の流動特性は, 円柱モデル流入口の流速がモデル下部で多少 千鳥配列よりも小さい程度である以外に，上部ほど減少する傾向には変わりない，この結果流入方向もモデル下部で幾 分千鳥配列の場合の $\alpha=80^{\circ}$ より小さく, モデル左下部の止水域の範囲も減少した. 中部では下部よりも $\alpha$ はさくな る. しかし, 千鳥配列の場合, 流入角 $\alpha$ が 1 列目まで持続したのが碁盤配列では 2 列目まで維持される. 2 列目以降, 流動角度は減少する が,千鳥配列よりも減 少の程度は小さい.こ の結果モデル内部で も流動角度は大きく， 出口で再び角度を増 し流出するまで傾斜 した流れが持続する などの特徵が観察さ れた.この結果モデル 中部では比較的広い 範囲で碁盤配列を斜 めに貫通する流れが 得られる. よって, 各 円柱には乱流剥離に 伴う後流が形成され ていると判断され,千 鳥配列と比較して熱 交換性能の向上も期 待できる.モデル上部

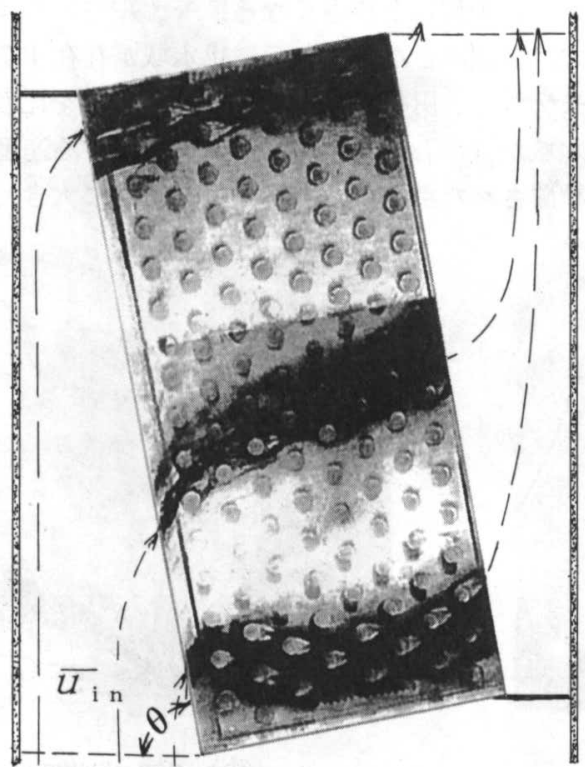

(a) staggered arrangement

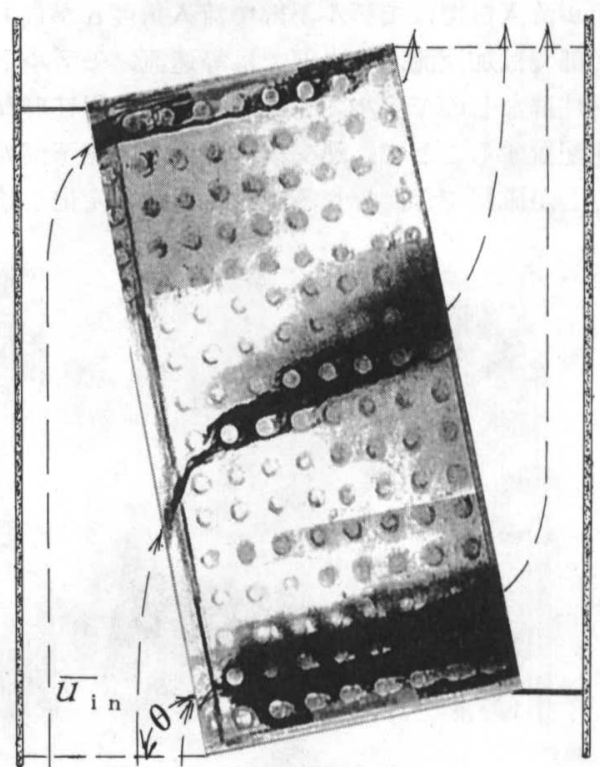

(b) in-line arrangement

Fig.6 Comparison of flow characteristics by the columns arrangement $\left(\theta=80^{\circ}, R e=1300\right)$

では千鳥配列と同様に $\alpha$ は小さく, 流入後は加速しモデル上壁と平行な方向に流れる. 以上の結果, 千鳥・碁盤各配列 ともに円柱群の各表面の境界層の発達状況は多様でかつ複雑であり, 円柱モデルによる流動からのみでは、熱交換器と しての総合的な流動損失特性, 熱交換特性を評価するまでには至らない.

\section{7. 結 論}

(1). 熱交換器モデル の設置角度 $\theta$ は, 円柱群内部の流動特性に与える影響が大きいことが確認された.

(2). 実機装置のように熱交換器の傾斜角度 $\theta$ が大きい場合, 熱交換器左下部及び下壁近傍は止水域となり, 装置の伝 熱性能を低下させる要因となる.

(3). 碁盤配列はモデル中部の流動の傾斜が千鳥配列より比較的広い範囲で維持され, 熱交換特性の向上が期待できる.

\section{参考文献}

1) 瀬下 · 藤井, 機論, 86-0798B, 1987. 2) 瀬下 - 藤井, 機論, 86-0799B, 1987. 3) 瀬下・藤井, 機論, 86-0797B, 1987. 4) 喜久川・山口・坂本, 可視化シンポ, Vol. 16, Supp1. No. 1, 1996. 5) 喜久川・山口・坂本, 空気調和・冷 凍講論, No. 31, 1997. 